Article

\title{
Estimation and Validation of RapidEye-Based Time-Series of Leaf Area Index for Winter Wheat in the Rur Catchment (Germany)
}

\author{
Muhammad Ali ${ }^{1, *}$, Carsten Montzka ${ }^{1}$, Anja Stadler ${ }^{2}$, Gunter Menz ${ }^{3}$, Frank Thonfeld ${ }^{4}$ \\ and Harry Vereecken ${ }^{1}$
}

1 Agrosphere (IBG-3), Research Center Jülich GmbH, Wilhelm-Johnen-Straße, 52428 Jülich, Germany; E-Mails: c.montzka@fz-juelich.de (C.M.); h.vereecken@fz-juelich.de (H.V.)

2 Institute of Crop Science and Resource Conservation, University of Bonn, Katzenburgweg 5, 53115 Bonn, Germany; E-Mail: astadler@uni-bonn.de

3 Remote Sensing Research Group, Department of Geography, University of Bonn, Meckenheimer Allee 166, 53115 Bonn, Germany; E-Mail: g.menz@uni-bonn.de

4 Centre for Remote Sensing of Land Surfaces (ZFL), University of Bonn, Walter-Flex-Straße 3, 53115 Bonn, Germany; E-Mail: frank.thonfeld@ uni-bonn.de

* Author to whom correspondence should be addressed; E-Mail: m.ali@fz-juelich.de;

Tel.: +49-2461-618-672.

Academic Editors: Clement Atzberger and Prasad S. Thenkabail

Received: 13 August 2014 / Accepted: 27 February 2015 / Published: 10 March 2015

\begin{abstract}
Leaf Area Index (LAI) is an important variable for numerous processes in various disciplines of bio- and geosciences. In situ measurements are the most accurate source of LAI among the LAI measuring methods, but the in situ measurements have the limitation of being labor intensive and site specific. For spatial-explicit applications (from regional to continental scales), satellite remote sensing is a promising source for obtaining LAI with different spatial resolutions. However, satellite-derived LAI measurements using empirical models require calibration and validation with the in situ measurements. In this study, we attempted to validate a direct LAI retrieval method from remotely sensed images (RapidEye)

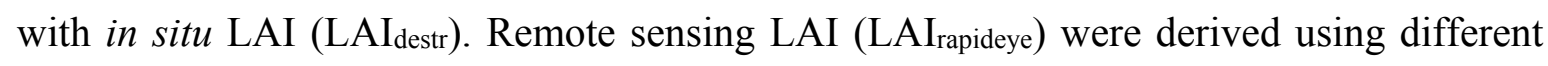
vegetation indices, namely SAVI (Soil Adjusted Vegetation Index) and NDVI (Normalized Difference Vegetation Index). Additionally, applicability of the newly available red-edge band (RE) was also analyzed through Normalized Difference Red-Edge index (NDRE) and Soil Adjusted Red-Edge index (SARE). The LAI rapideye $_{\text {obtained from vegetation indices }}$
\end{abstract}


with red-edge band showed better correlation with LAIdestr $(r=0.88$ and Root Mean Square Devation, RMSD $=1.01 \& 0.92$ ). This study also investigated the need to apply radiometric/atmospheric correction methods to the time-series of RapidEye Level 3A data prior to LAI estimation. Analysis of the the RapidEye Level 3A data set showed that application of the radiometric/atmospheric correction did not improve correlation of the estimated LAI with in situ LAI.

Keywords: leaf area index; red-edge band; RapidEye; atmospheric correction; validation; time-series

\section{Introduction}

Interactions among vegetation, soil, energy fluxes and carbon cycle have profound impacts on the climate system [1,2]. Vegetation greatly influences the climatic conditions prevailing in an area through modification of the hydrologic fluxes, such as transpiration/evaporation and interception [3]. Therefore, indices describing vegetation properties, e.g., Leaf Area Index (LAI), contain important information that can be used to characterize vegetation dynamics and evapotranspiration fluxes in climate and hydrological models $[4,5]$. To achieve better agricultural productivity, adequate information on climatic variables and physical landscape properties is required which can be provided by remote sensing in a timely and operational manner [6] from field scale to regional scale [7]. LAI is an important bio-physical variable [8] for various models used in hydrology, climatology and crop growth, and is defined as the ratio of total upper leaf area per unit surface area of the ground $\left(\mathrm{m}^{2} / \mathrm{m}^{2}\right)$. Accurate and timely estimates of LAI are useful for production estimation and stress evaluation of crops and environmental changes [9]. There are several methods for measuring LAI whereby in situ measurements are the most reliable. However, in situ measurements of LAI are labor intensive and site specific so that an extrapolation to regional scale is limited. There are several approaches for estimating LAI from remotely sensed data, generally grouped into physical models and empirical models. Physical models include canopy reflectance models such as SAIL [10] and PROSAIL [11] to simulate the canopy reflectance as a function of canopy variables (including LAI). For instance, Haboudane et al. [12] simulated leaf and canopy reflectance spectra using PROSAIL to estimate LAI. Empirical models relate in situ LAI measurements to remotely-sensed vegetation indices using statistical transfer functions [13-18]. Atzberger et al. [19] analyzed two full spectrum methods using hyperspectral data (i.e., principal component regression (PCR) and partial least square regression (PLSR)] based on a leave-one-out (LOO) approach [20,21] to derive chlorophyll content in winter wheat. Despite requiring significant computational resources, models simulating the physical processes are preferred for accuracy and transferability [22]. Sometimes, they even outperform empirical approaches (e.g., NN, neural network approach) [23]. Asrar et al. [24] established a procedure to estimate LAI and FPAR (fraction of photosynthetically active radiation) from spectral reflectance. LAI and spectral reflectance are interrelated [24,25] and many relationships have been developed between vegetation indices (combination of reflectance) and various vegetation parameters e.g., LAI, FPAR, chlorophyll concentration and biomass etc. [12,25]. Deng et al. [22] used the simple ratio (SR) and the reduced 
simple ratio (RSR) to retrieve global and regional LAI maps. According to Walthall et al. [17], using scaled NDVI (Normalized Difference Vegetation Index) without site specific calibration measurements is an efficient method to retrieve LAI. Areas of green leaves exhibit more spatio-temporal variability and have more influence on the red and near infra-red radiation in the canopy; therefore, many studies have incorporated reflectance data in these spectral regions to estimate LAI for large areas [9]. Several VI have been developed, but we selected the most widely used indices i.e., the NDVI [26] and its modified form to correct for soil reflectance the SAVI [27] along with their red-edge based modifications.

Presently, several remote sensors are operational that provide vegetation-related information with different spatial and temporal resolutions. Multispectral optical remote sensing techniques give more direct estimates of vegetation characteristics using the unique spectral reflectance [28], whereas microwave methods provide more information on the structural characteristics of vegetation [29]. Some of the remote sensing based data sources for vegetation monitoring include: AVHRR (Advanced Very High Resolution Radiometers [30]), Landsat [18,31-35], MODIS (Moderate Resolution Imaging Spectroradiometer), MISR (Multi-angle Imaging SpectroRadiometer), VIIRS (Visible/Infra-red Imager Radiometer Suite), SPOT-VEGETATION (Systeme Pour l'Observation de la Terre), multispectral EO-1 Hyperon [36] and airborne multispectral HyMap [37]. In this study, we have used the relatively new satellite system, RapidEye. To analyze the performance in estimating LAI time-series, we used RapidEye's high spatio-temporal resolution and its newly available red-edge spectral band (RE $(0.690-0.730 \mu \mathrm{m})]$. Here, we have attempted to validate the methodology previously used for MODIS LAI [38-40] to directly map LAI on high spatial resolution (5 m) satellite imagery from RapidEye.

RapidEye's satellites are the first commercial satellites to include a high spatial resolution red-edge band, representing the wavelength region that exhibits rapid change in the reflectivity of vegetation from red (more absorption/low reflectance) to near infra-red (NIR, maximum reflectance) [9,41]. Numerous studies have been carried out using the red-edge spectral information. Darvishzadeh et al. [42] derived LAI from (ground based) hyper-spectral vegetation indices and red-edge inflection point (REIP), but the REIP showed very poor correlation with LAI. Vuolo et al. [23] used multispectral RapidEye images to estimate LAI, canopy chlorophyll content (CCC) and leaf chlorophyll content (LCC). Ehammer et al. [43] used RapidEye images to determine the fraction of incident photosynthetically active radiation (FPAR) and LAI of cotton and rice using the red-edge spectral information in calculating vegetation indices, but use of the red-edge band did not improve the vegetation indices. Eitel et al. [44] studied early stress detection by examining utility of the red-edge and non-red-edge vegetation indices calculated on a time-series of 22 RapidEye images of a piñon-juniper woodland in central New Mexico. Schuster et al. [45] investigated the improvement of land use classification, especially in vegetation classes, using a RapidEye scene from July 2009 of a study site in Berlin (Germany). Filella and Penuelas [46] have confirmed high sensitivity of the red-edge spectral band to chlorophyll content of vegetation. Previous studies using RapidEye images [23,43,47] did not discuss the benefits of the multi-temporal red-edge spectral band from RapidEye [48]. Asam et al. [48] derived LAI for grassland in Bavarian alpine upland (Germany) on RapidEye imagery. Here, we investigate the retrieval of LAI time-series from vegetation indices with the red-edge spectral band, and correlate with in situ vegetation observations covering various stages of winter wheat growth.

Radiation from the earth surface interacts strongly with the atmosphere [49]. This interaction affects in particular the time-series of vegetation observations under different atmospheric conditions. 
Variations in atmospheric conditions, sun-target-sensor geometries and illumination conditions lead to variations in satellite images acquired on different days of the year. Two approaches have been described in the scientific literature to account for these differences: absolute and relative correction [50]. The absolute approach needs in situ optical properties of the atmosphere at the time of image acquisition [51]. In the relative method, one image (target) is radiometrically normalized with another image (reference) acquired under the best optical properties of the atmosphere [50]. In this study, effect of both the absolute and relative atmospheric correction on a time-series of RapidEye imagery was evaluated by the performance of the LAI estimation.

The objectives of this study are: (i) to evaluate the usability of RapidEye to derive LAI time-series for winter wheat; (ii) to investigate the need for absolute and relative atmospheric/radiometric correction; (iii) to analyze the role of the red-edge band in LAI estimation; and (iv) to evaluate the impact of soil contribution on LAI time-series using SAVI as vegetation index.

\section{Study Area}

The area under investigation in this study is the Rur catchment (Figure 1), located in the Germany-Belgium-Netherlands border area, near the city of Aachen [52,53]. The TERENO-initiative (Terrestrial Environmental Observatories [54] has established several test sites at different locations within this catchment covering cropland (Selhausen and Merzenhausen in Figure 1), grassland (Rollesbroich in Figure 1) and forests (Wuestebach in Figure 1) [55,56]. The southern part of the catchment is covered by the bedrock of the Eifel Mountains with a high annual precipitation and a moderate potential evapotranspiration, while the northern part receives relatively low annual precipitation and higher potential evapotranspiration [57]. Winter wheat and sugar beet are the main crops cultivated in the area.

The Selhausen test field (area $\approx 0.8$ hectare) is located in the southern part of the Lower Rhine Embayment, in the vicinity of the Rur river (near Dueren city) [58]. The area is covered with Quaternary sediments, mostly fluvial deposits from the Rhine/Maas River and the Rur river system [59]. They form the underlying sediments, whereas floodplain sediments belong to Pleistocene and Holocene sediments. Weakly inclined $\left(<4^{\circ}\right)$ in the east-west direction, high gravel content is present in the upper (eastern) part of the site [60]. Due to the specific geomorphology and textural properties, the soil surface water content is highly variable in space [60].

The other test area, Merzenhausen (area $\approx 7$ hectares), is located approximately $12 \mathrm{~km}$ from the northwest of the Selhausen test site, near Juelich (Germany). Geomorphologically weakly inclined and structured on a high terrace of the Rur river, the area is composed of fluvial deposed loess of Pleistocene/Holocene and with small gravels up to a depth of $165 \mathrm{~cm}$ [61].

\section{RapidEye and In Situ Measurements}

\subsection{RapidEye Data}

RapidEye data are available in five different spectral bands (Figure 2), i.e., blue (0.440-0.510 $\mu \mathrm{m})$, green $(0.520-0.590 \mu \mathrm{m})$, red $(0.630-0.685 \mu \mathrm{m})$, red-edge $(0.690-0.730 \mu \mathrm{m})$ and near infra-red (NIR $(0.760-0.850 \mu \mathrm{m}))$. With a constellation of five identically constructed satellites, RapidEye is able 
to provide daily multispectral imagery in $6.5 \mathrm{~m}$ spatial resolution. During orthorectification to a map projection, the pixel size of $6.5 \mathrm{~m}$ with $77 \mathrm{~km}$ swath width $[43,47]$ has been resampled to $5 \mathrm{~m}$ and provided as Level 3A data. These Level 3A (standard L3A) products were already radiometrically corrected through sensor calibration based on the statistics from all incoming imagery data, absolute ground calibration campaigns and image acquisitions over selected temporal calibration sites located worldwide [62]. In total, 24 scenes were available for 2011 and 2012 covering two winter wheat growing seasons. For validation purpose, we considered only those images for which in situ LAI measurements were taken. When the in situ and satellite acquisition date did not coincide, a nearest available image (date wise) to the in situ measurement was used (Table 1).

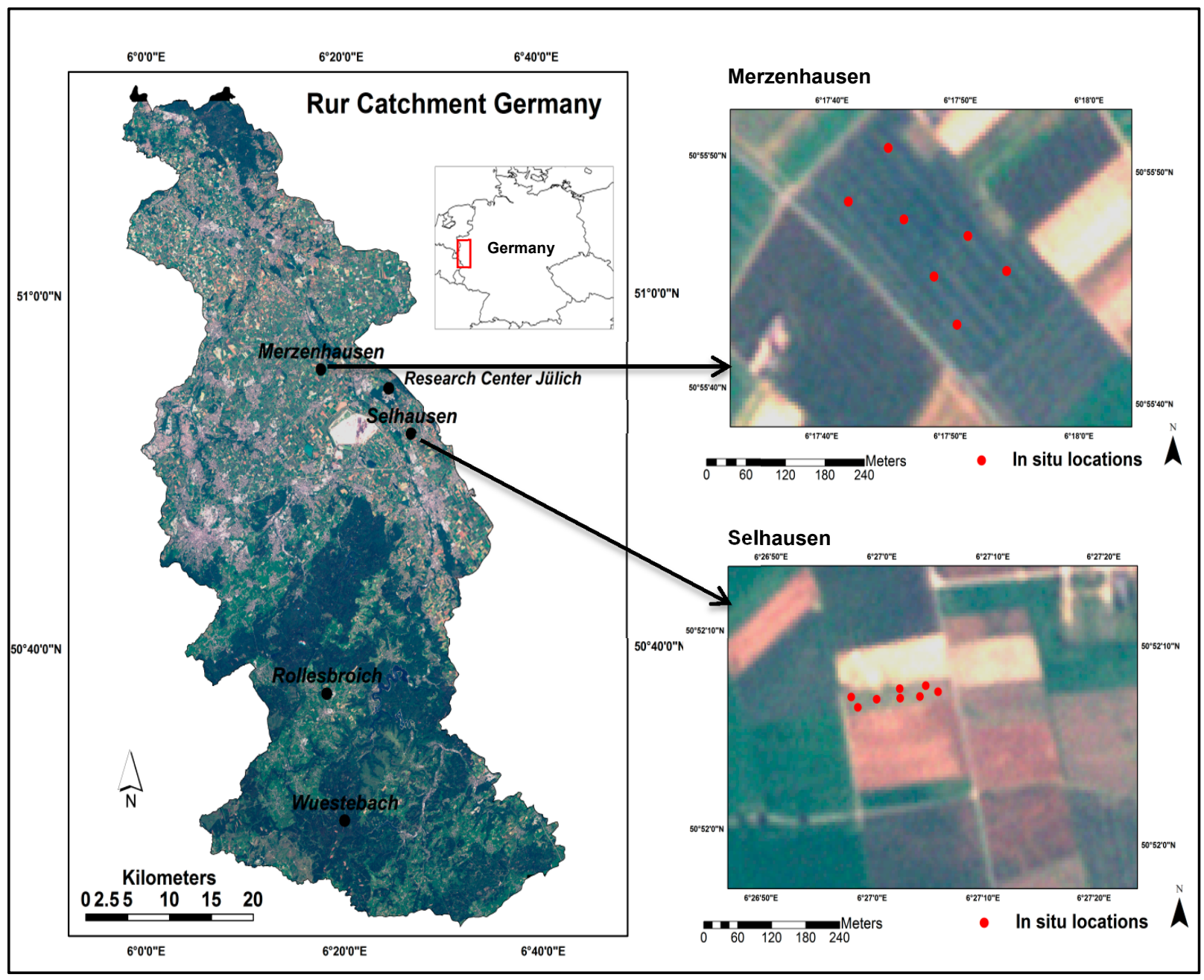

Figure 1. The Rur Catchment (Germany), as seen by RapidEye on 27 June 2011. Individual test sites at Selhausen and Merzenhausen are shown with sampling points.

\subsection{In Situ LAI Measurements (LAIdestr)}

In situ LAI measurements were taken at several points within the winter wheat fields using destructive method, LI-COR LI 3100C (LAI destr). Destructive methods ( LAI $_{\text {destr) }}$ produce more reliable results and provide a reference for the calibration of non-destructive measurements [63] including in situ LAI (non-destructive) and remotely sensed LAI. The destructive methods involved physical removal of above ground vegetation within a defined area. Eight and seven collection points were selected for 
in situ measurements inside the Selhausen and the Merzenhausen test fields, respectively. The in situ LAI collection points were evenly distributed within the test fields (Figure 1) and remote sensing based LAI was acquired from the same points within the test fields. In the study area, winter wheat is usually sown mid November and harvested at the end of July or start of August. Each year, the measurement campaign was started in March and carried out until the harvest time (July/August). The in situ data were collected twice a month during the growing season (March-July/August) of 2011 and 2012 [64]. The time-series of LAI calculated on RapidEye images ( $\mathrm{LAI}_{\text {rapideye }}$ ) were correlated with the time-series of destructive LAIdestr. Table 1 shows the availability of in situ LAI (LAIdestr) data along with the date and time of acquisition of RapidEye. To compare in situ LAI (measured in a $1 \times 1 \mathrm{~m}$ space) to satellite derived LAI (on $5 \mathrm{~m}$ spatial resolution), field averages were calculated.

Table 1. In situ Leaf Area Index (LAI) and RapidEye time-series available for this study at both test fields.

\begin{tabular}{|c|c|c|c|c|c|}
\hline \multicolumn{3}{|c|}{ Selhausen } & \multicolumn{3}{|c|}{ Merzenhausen } \\
\hline RapidEye & $\begin{array}{c}\text { RapidEye } \\
\text { Acquisition Time } \\
\text { (UTC) }\end{array}$ & $\begin{array}{c}\text { Destructive } \\
\text { LAI }\end{array}$ & RapidEye & $\begin{array}{c}\text { RapidEye } \\
\text { Acquisition } \\
\text { Time (UTC) }\end{array}$ & $\begin{array}{c}\text { Destructive } \\
\text { LAI }\end{array}$ \\
\hline \multicolumn{3}{|c|}{2011} & \multicolumn{3}{|c|}{2011} \\
\hline 07 April & $11: 42: 30$ & 07 April & 02 April & $11: 37: 42$ & 29 March \\
\hline 24 April & $11: 42: 04$ & 18 April & 07 April & $11: 42: 27$ & 15 April \\
\hline 10 May & $11: 34: 49$ & 03 May & 02 May & $11: 28: 02$ & 04 May \\
\hline 21 May & $11: 44: 59$ & 18 May & 21 May & $11: 44: 56$ & 23 May \\
\hline 30 May & $11: 34: 32$ & 03 June & 01 June & $11: 39: 51$ & 11 June \\
\hline 27 June & $11: 43: 00$ & 27 June & 27 June & $11: 42: 57$ & 20 June \\
\hline 01 September & $11: 28: 44$ & 30 August & & & \\
\hline \multicolumn{3}{|c|}{2012} & & & \\
\hline 03 April & $11: 39: 35$ & 30 March & & & \\
\hline 25 May & $11: 30: 21$ & 25 May & & & \\
\hline 08 June & $11: 47: 27$ & 12 June & & & \\
\hline 26 July & $11: 32: 19$ & 24 July & & & \\
\hline
\end{tabular}

\section{Approach/Methods}

The main objective of this study was to derive an accurate and reliable time-series of LAI on multi-temporal RapidEye images for the two intensively investigated winter wheat fields in the Rur catchment. For this purpose, LAI was estimated through a logarithmic relationship between LAI and respective vegetation indices (e.g., NDVI, SAVI, and their respective red-edge based modifications)

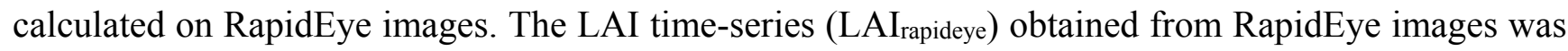
then validated with the time-series of destructive LAI measurements (LAIdestr) in order to choose a more optimized vegetation index. Validation results of the LAI calculated on RapidEye imagery (standard L3A and processed images (atmospheric/radiometric correction)) with destructive LAIdestr were mutually compared. A flowchart (Figure 3) summarizes different vegetation indices and various approaches adopted for this study. 


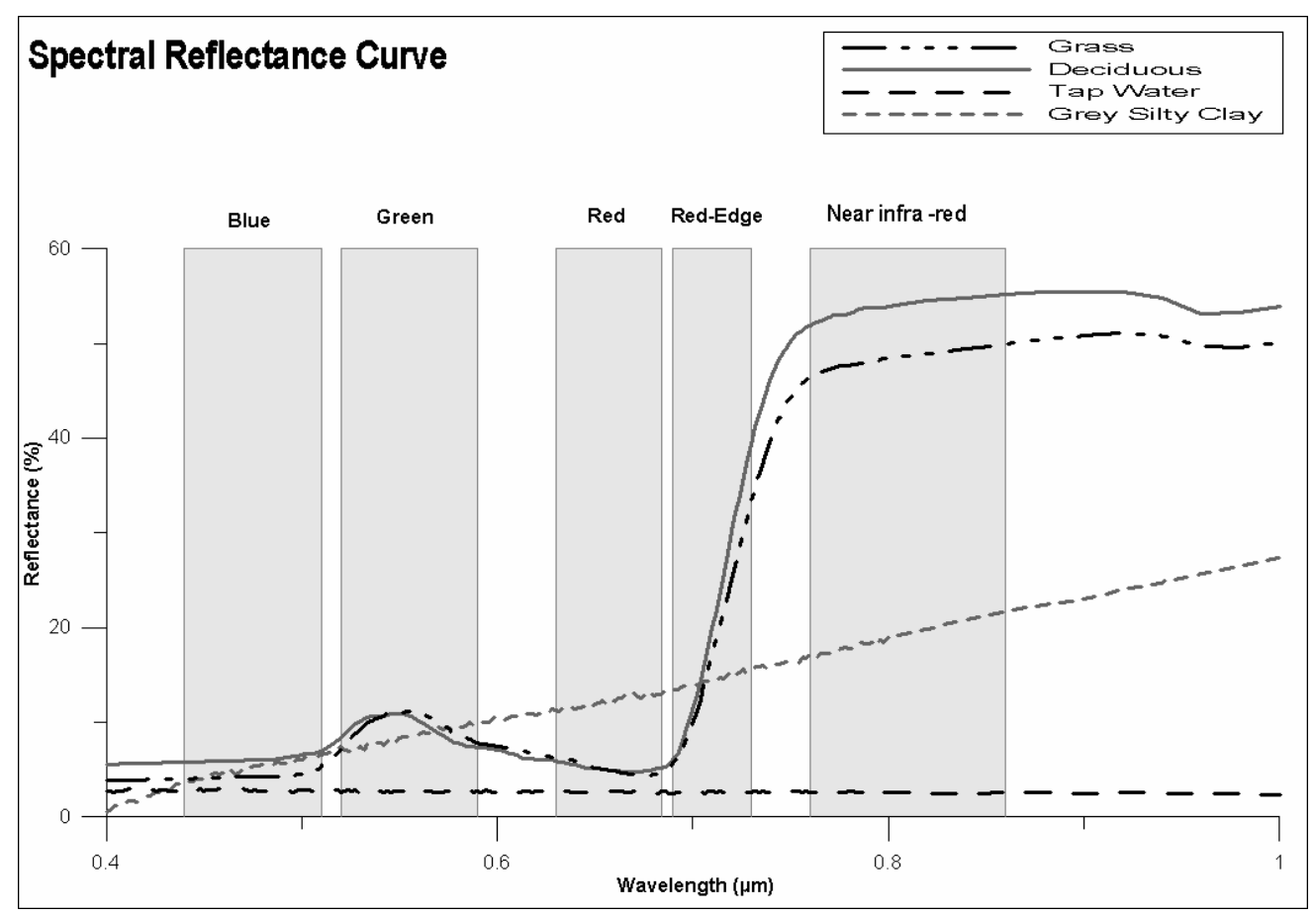

Figure 2. Spectral Reflectance Curves for various features of the land surface plotted against different RapidEye's spectral channels. Vertical bars represent spectral bands of the RapidEye imagery. (Source for the reflectance data is ASTER Spectral Library).

\subsection{The Need for Radiometric/Atmospheric Correction}

In this study, LAI computation on RapidEye imagery is based on several vegetation indices (NDVI, SAVI, NDRE and SARE). These indices are already normalized where difference of two spectral bands is normalized by the sum of the same spectral bands. Different atmospheric conditions affect the absolute reflectance of each band. Therefore, the necessity for absolute and relative radiometric/atmospheric correction needs to be analyzed. Here, we focused on the correlation between in situ LAI (LAI destr) and three processing levels for considering the radiometric/atmospheric conditions: (i) relative radiometric normalization; (ii) specific absolute atmospheric correction; and (iii) standard RapidEye Level 3A delivery without further processing.

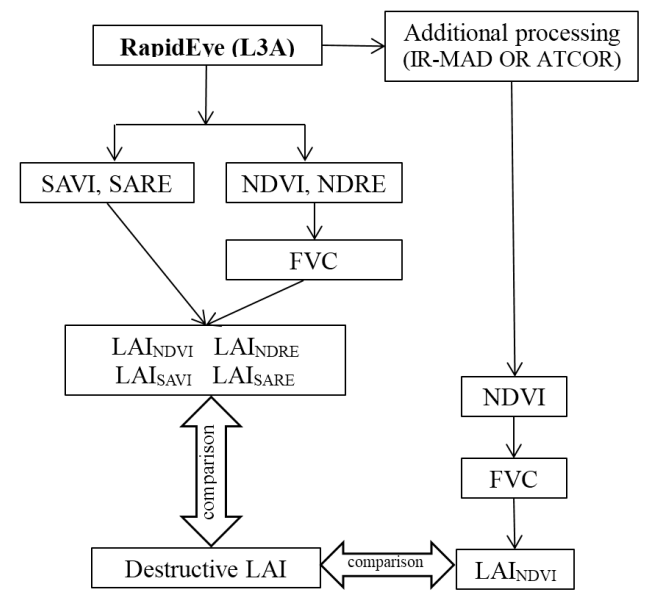

Figure 3. Flowchart description of the study. 
The method used for relative radiometric normalization was the Iteratively Reweighted-Multivariate Alteration Detection (IR-MAD) $[65,66]$. The band-wise IR-MAD transformation was applied to a set of bi-temporal satellite images (all five bands) to select invariant pixels from the two dates, i.e., reference image and target image. Satellite images acquired under the most appropriate atmospheric and illumination conditions were taken as reference to normalize the target. Generally, the satellite image acquired on 27 June 2011 was used as the reference image in this study. If there was a large time gap between reference image and target images, it became difficult to find enough pseudo-invariant pixels for adequate normalization. Then, a temporally close, already normalized image (April) was selected as the reference image. The resultant normalized target image should appear as if it were acquired with the same sensor and atmospheric conditions of the reference image [51].

For absolute radiometric/atmospheric correction, the Atmospheric Correction Algorithm, ATCOR-2 [67,68] was applied to the time-series of RapidEye imagery. The ATCOR-2 incorporates image center (nadir)-based date, season and landuse-based atmospheric visibility, aerosol types (i.e., rural, urban, desert, maritime, spring, summer and winter etc.), spacecraft view angle, illumination azimuth angle and illumination elevation angle for the respective RapidEye image. Typically, ATCOR-2 is applied to flat terrains, which is given for the agriculturally intensively used region under investigation with $60 \mathrm{~m}$ average elevation.

\subsection{Estimation of LAI Time-Series from RapidEye}

First, NDVI (Normalized Difference Vegetation Index) was calculated. NDVI is the difference of the reflectance at near infra-red (NIR) and Red (RED) spectral bands normalized by the sum of the reflectance at these spectral bands (Equation (1)).

$$
N D V I=\frac{N I R-R E D}{N I R+R E D}
$$

NDVI [26] has wide applications providing information about vegetation and chlorophyll content in leaves. NDVI has good potential to extract useful information regarding dynamic changes in different vegetation types, making it a good indicator for investigating such changes temporally [28,69]. Beck et al. [70] presented a double logistic function for modeling time-series of MODIS NDVI for higher

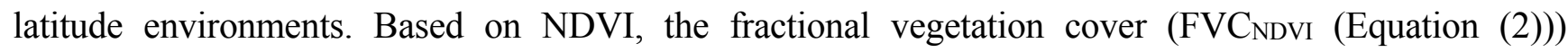
was derived:

$$
F V C_{N D V I}=\frac{N D V I-N D V I_{s}}{N D V I_{v}-N D V I_{s}}
$$

as used by Zeng et al. and Xiao and Moody [71-73]. Here, NDVI represents the NDVI values for bare soil while NDVI represents the NDVI values at full vegetation cover in respective images of the time-series. The FVC was calculated to avoid mixed signals in satellite data [73]. For this purpose, NDVI was scaled between lowest NDVI (bare soil) and highest $\mathrm{NDVI}_{\mathrm{v}}$ (dense vegetation) to calculate fractional vegetation cover (Equation (2)). For this model, $\mathrm{NDVI}_{\mathrm{s}}$ and $\mathrm{NDVI}_{\mathrm{v}}$ were selected through histogram evaluation. Subsequently, LAI was calculated through a given logarithmic relation (Equation (3)) between respective $\mathrm{FVC}_{\mathrm{NDVI}}$ and $\mathrm{LAI}[38,74]$.

$$
L A I_{N D V I}=\frac{-\log \left(1-F V C_{N D V I}\right)}{k(\theta)}
$$


Here, $\mathrm{k}(\theta)$ is the light extinction coefficient for a given solar zenith angle. The solar zenith angle $(\theta)$ depends on terrain geometry, solar declination, solar elevation angle, latitudinal location and day of the year [40]. The light extinction coefficient is a measure of attenuation of radiation in the canopy. The model parameter, $\mathrm{k}(\theta)$, was calibrated with in situ LAI (also see Section 5.2). Here, the aim was first to find a good correlation (r), whereas the estimated LAI magnitudes may not be in line with in situ LAI in terms of absolute prediction accuracy i.e., Root Mean Square Deviation (RMSD (Equation (4))). Number of observations " $n$ " were different for both test sites under investigation (" $n=11$ " for Selhausen and " $n=6$ " for Merzenhausen (Table 1)). Second, the subsequent selection of adequate $\mathrm{k}(\theta)$ will focus on the improvement of the RMSD. The extinction coefficient was optimized to

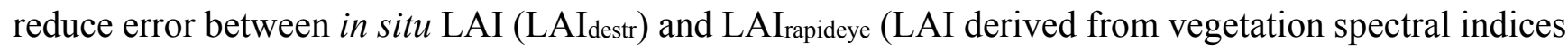
e.g., LAINDVI).

$$
R M S D=\sqrt{\sum_{i=1}^{n} \frac{\left(L A I_{\text {rapideye }}(i)-L A I_{\text {destr }}(i)\right)^{2}}{n}}
$$

A spatial separation into a calibration and a validation data set is performed in order to independently optimize $\mathrm{k}(\theta)$ and validate the LAIrepideye results. Three points per field were selected for validation, whereas the point combination with the maximum distance sum was selected to adequately cover the within-field heterogeneity. The residual points were used for $\mathrm{k}(\theta)$ calibration.

\subsection{Impact of the Soil Contribution on LAI Calculation}

The soil contribution to the reflectance in crop fields can be relatively high, especially in the early stages of crop growth, which can cause inaccurate estimates of LAI. To account for this, we also utilized the Soil Adjusted Vegetation Index (SAVI), developed by Huete [27], as vegetation index for LAIsAVI estimation. The SAVI algorithm (Equation (5)) [27] has the same structure as NDVI with a modification to correct for the influence of the soil brightness of bare soils or soils with low vegetation.

$$
S A V I=\left(\frac{N I R-R E D}{(N I R+R E D)+L}\right) 1+L
$$

where L stands for soil brightness correction factor and its value is 0 for dense vegetation and 1 for bare soil [27]. Here, $\mathrm{L}=0.25$ was used keeping in view the status of vegetation availability during the $i n$ situ measurement campaign. Like NDVI, SAVI was also used for LAI calculation using Equation (3), however, unlike NDVI, SAVI is directly used in Equation (3) without FVC calculation. SAVI reduces the impact of soil reflectances by incorporating the soil brightness correction factor (L). Therefore calculation of FVC before LAI estimation was not considered here.

\subsection{Role of the Red-Edge Band}

The red-edge spectral band represents portion of the spectral reflectance where rapid changes occur in the reflectivity of vegetation (Figure 2). We have evaluated this portion of the solar spectrum (captured by RapidEye system) for vegetation by incorporating it into the vegetation indices for LAI calculation (i.e., LAINDRE and LAISARE). Red-edge based vegetation indices i.e., the Normalized Difference Red-edge index (NDRE (Equation (6)) [75-77]) and the Soil Adjusted Red-edge index (SARE 
(Equation (7))), are calculated by replacing the red spectral band $(0.630-0.685 \mu \mathrm{m})$ with the red-edge (RE) spectral band $(0.690-0.730 \mu \mathrm{m})$ in Equation (1) (NDVI) and Equation (5) (SAVI). The RE spectral band is more sensitive towards vegetation than the RED spectral band (Figure 2). The modified form of Equations (1) and (5) for RE are shown as Equations (6) and (7).

$$
\begin{gathered}
N D R E=\frac{N I R-R E}{N I R+R E} \\
S A R E=\left(\frac{N I R-R E}{(N I R+R E)+L}\right) 1+L
\end{gathered}
$$

The new RE-based indices were renamed as Normalized Difference Red-edge index (NDRE) and Soil Adjusted Red-edge index (SARE) for NDVI and SAVI, respectively.

\section{Results and Discussion}

\subsection{Impact of the Absolute and Relative Atmospheric/Radiometric Correction}

One example of an additional atmospheric correction to the L3A data set is presented in Figure 4. Here, it shows the difference in the visual appearance (i.e., natural color composite display) of standard L3A RapidEye (A), and IR-MAD corrected (C) images from the mosaic, while part B represents the reference image for IR-MAD normalization. In Figure 4, part A and C were acquired on 2 April 2011 while part B was acquired on 24 April 2011. Due to the normalization procedure, part C compares well to part B. This improvement needs to be verified statistically. Changes due to the phenological cycle are visible from $\mathrm{B}$ to $\mathrm{C}$.

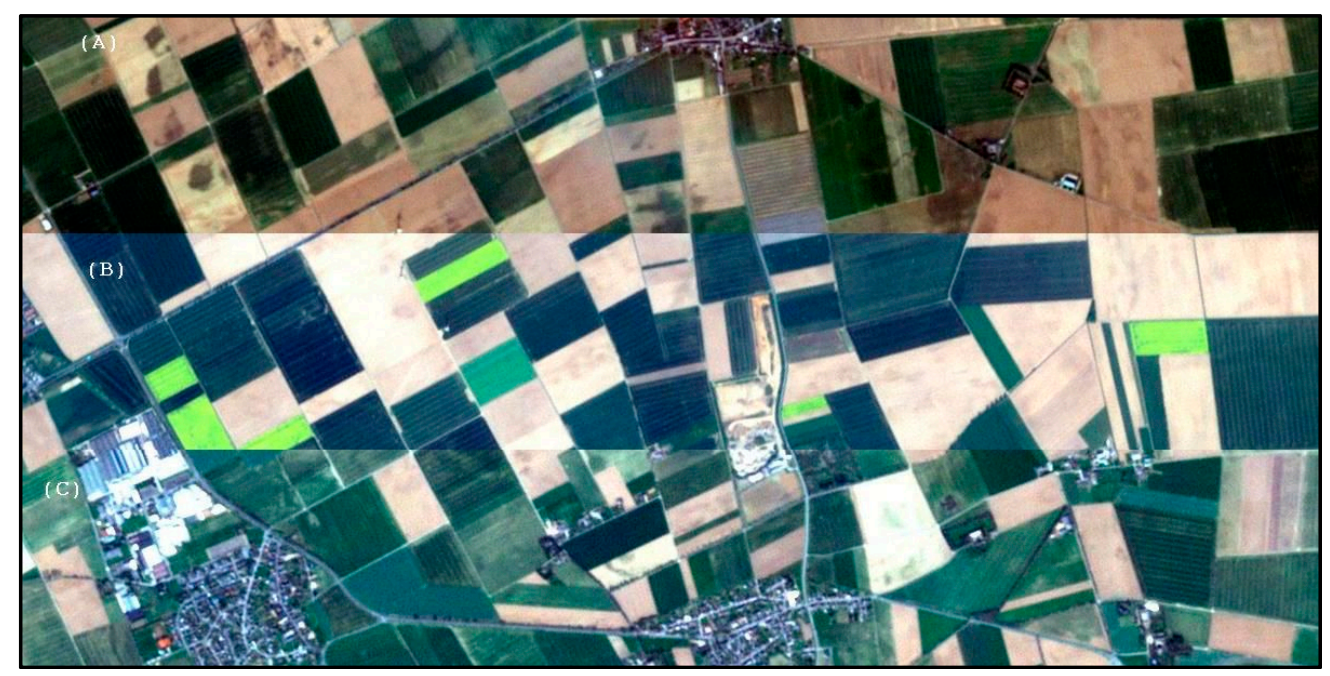

Figure 4. Part of the standard L3A RapidEye image from 2 April 2011 (A); The reference image dated 24 April 2011 (B); IR-MAD processed image (C). RGB band combinations are 3-2-1.

For a single date, the results of different atmospheric correction strategies are highly correlated. However, the regression slope is different for each date, which affects the time-series analysis for a single pixel. Therefore, the analysis of different atmospheric correction strategies is mandatory prior to LAI time-series analysis. Before deriving LAI, different vegetation indices (i.e., NDVI, SAVI, NDRE 
and SARE), based on the standard L3A, IR-MAD and ATCOR processed RapidEye imagery were directly compared to LAIdestr (Table 2). Table 2 shows higher correlation coefficients for standard L3A RapidEye spectral indices with LAIdestr than the IR-MAD processed vegetation indices at both test sites. However, ATCOR works well at the Merzenhausen site and presents higher correlations than L3A and IR-MAD except for red-edge based indices (NDRE and SARE) where " $r$ " is similar for L3A and ATCOR imagery. All correlations are statistically significant $(p<0.05)$ except the NDVI and SAVI (IR-MAD processed) at the Merzenhausen winter wheat field.

Table 2. Direct comparison of different spectral vegetation indices calculated on RapidEye L3A, IR-MAD and ATCOR processed RapidEye data with LAIdestr for winter wheat at two different locations. Top numbers in each cell represent the $r$ for the Selhausen field (2011-2012), the bottom numbers in each cell represent the Merzenhausen field (2011), in brackets the significance level ( $p$-value) is given.

\begin{tabular}{cccc}
\hline \multirow{2}{*}{ Spectral Vegetation Index } & \multicolumn{3}{c}{ Atmospheric Correction Methods } \\
\cline { 2 - 4 } & L3A & IR-MAD & $0.60(0.040)$ \\
\multirow{2}{*}{ NDVI } & $0.85(0.0005)$ & $0.72(0.0077)$ & $0.90(0.012)$ \\
\hline \multirow{2}{*}{ NDRE } & $0.85(0.033)$ & $0.77(0.075)$ & $0.68(0.014)$ \\
& $0.90(0.0001)$ & $0.70(0.0104)$ & $0.92(0.007)$ \\
\hline \multirow{2}{*}{ SAVI } & $0.92(0.009)$ & $0.83(0.040)$ & $0.60(0.040)$ \\
& $0.85(0.0005)$ & $0.72(0.0081)$ & $0.90(0.012)$ \\
\hline \multirow{2}{*}{ SARE } & $0.85(0.033)$ & $0.77(0.075)$ & $0.68(0.014)$ \\
& $0.90(0.0001)$ & $0.70(0.0121)$ & $0.92(0.007)$ \\
\hline
\end{tabular}

As the overall correlation relationship between the different spectral vegetation indices is similar, and for simplification, the following analysis about the need for atmospheric correction for LAI derivation is based on NDVI-related spectral analysis only. For validating RapidEye-derived LAI, we used a general $\mathrm{k}(\theta)=0.25$ in Equation (3) for both test fields. Results are listed in Table 3. For these NDVI-based LAI (LAINDVI), ATCOR produced almost similar results like IR-MAD, whereas L3A was better correlated with in situ LAIdestr. Similar to direct comparison, LAINDVI derived from ATCOR processed imagery gave better correlation results for Merzenhausen $(r=0.89$, RMSD $=2.30)$. ATCOR processing works differently for two separate fields with different levels of surface heterogeneity in terms of vegetation health/density. However, with respect to lower RMSD and consistency of better validation results for two separate sites, the L3A RapidEye imagery is preferred. It is evident from the temporal sequence (Figure 5) and scatter plot (Figure 6) that the LAINDVI (L3A) data have comparatively less uncertainty. The LAINDVI after ATCOR and IR-MAD processing are more scattered as compared to the LAINDVI from RapidEye L3A imagery (Figure 6). The same scatter is visible in the temporal sequence (Figure 5) for LAINDVI calculated on IR-MAD/ATCOR processed imagery. However, all the correlations are statistically significant $(p<0.05)$, except the IR-MAD processed LAINDVI $(p=0.138)$ at Merzenhausen (Table 3), which is not significant $(p>0.05)$. The LAINDVI calculated on the standard RapidEye L3A imagery show better correlation with the destructive LAI $\mathrm{L}_{\text {destr }}(r=0.82$ and 0.78 for Selhausen and Merzenhausen, respectively (Table 3)). 
Table 3. Comparison of the LAINDvi (RapidEye standard L3A, IR-MAD and ATCOR processed) with LAIdestr, in winter wheat fields at Selhausen and Merzenhausen test sites. (Numbers in bold represent the best correlation in a column while underlined numbers represent the insignificant correlation).

\begin{tabular}{|c|c|c|c|c|c|c|}
\hline \multirow{2}{*}{$\begin{array}{l}\text { LAI } I_{\text {rapideye }} \text { vs. } \text { LAI }_{\text {destr }} \\
\text { for Winter Wheat }\end{array}$} & \multicolumn{3}{|c|}{ Selhausen (2011-2012) } & \multicolumn{3}{|c|}{ Merzenhausen (2011) } \\
\hline & $r$ & $p$-value & RMSD & $r$ & $p$-value & RMSD \\
\hline $\begin{array}{c}\mathrm{LAI}_{\mathrm{NDVI}}(\mathrm{L} 3 \mathrm{~A}) \\
(\mathrm{k}(\theta)=0.25)\end{array}$ & 0.82 & 0.0010 & 0.99 & 0.78 & 0.05 & 1.09 \\
\hline $\begin{array}{c}\mathrm{LAI}_{\mathrm{NDVI}}(\mathrm{IR}-\mathrm{MAD}) \\
(\mathrm{k}(\theta)=0.25)\end{array}$ & 0.71 & 0.0093 & 0.89 & 0.68 & $\underline{0.138}$ & 1.70 \\
\hline $\begin{array}{c}\mathrm{LAI}_{\mathrm{NDVI}}(\mathrm{ATCOR}) \\
(\mathrm{k}(\theta)=0.25)\end{array}$ & 0.68 & 0.014 & 0.91 & 0.89 & 0.016 & 2.30 \\
\hline
\end{tabular}

The preceding multispectral index of LAI (i.e., NDVI) is already normalized (difference of two spectral bands is normalized by the sum of the same spectral bands). This normalization could be a possible reason why absolute and relative atmospheric/radiometric corrections (normalization) do not satisfy our basic assumption for using them. The absolute and relative atmospheric/radiometric corrections normalize satellite images to the best atmospheric and illumination conditions in an absolute and relative way, respectively. They remove or minimize the influence of varying atmospheric and illumination conditions [68]. Use of additional radiometric correction may generate some unavoidable uncertainties in the remote sensing data [78] which is also evident in this study for ATCOR/IR-MAD processed LAINDVI with LAIdestr (Figures 5 and 6). The effect of additional noise due to additional absolute and relative radiometric/atmospheric processing may be more prominent when bare soil reflectance is dominant over vegetation (Figure 5). Moreover, the reduced sunlight during Northern hemisphere winter (Figure 5) firstly increases the noise-to-signal ratio at a passive sensor and secondly the different light characteristics during winter cannot be completely considered with the ATCOR and IR-MAD methods. Decrease in the correlation coefficients (r) for ATCOR/IR-MAD processed indices in Table 3 (except for ATCOR at Merzenhausen) is additional evidence of uncertainties in LAI estimation after the application of atmospheric/radiometric correction. Factors such as radiometry, the atmosphere, topography, sun glint effect and adjacent pixel influences, necessary for radiometric correction, are not fully corrected [79], and inappropriate use (or unavailability) of these variables makes the radiometric correction more challenging [78]. According to Qi et al. [80], the effect of atmospheric correction is not significant on remote sensing based estimation of vegetation variables. Comparison of the standard L3A and ATCOR/IR-MAD processed LAINDVI (Table 3 and Figures 5 and 6 ) with LAI destr for $_{\text {f }}$ both test sites make atmospheric/radiometric correction (ATCOR \& IR-MAD) unnecessary for this validation study for winter wheat based on RapidEye Level 3A images. During on-ground processing, radiometric and sensor calibrations/corrections are applied to the Level 3A RapidEye imagery [62]. Our results show that these calibrations (see Section 3.1) provide satisfying LAI estimates, and there is no need to apply any further calibration/normalization like ATCOR and IR-MAD. The following analyses are therefore based on the L3A product without further atmospheric correction. 


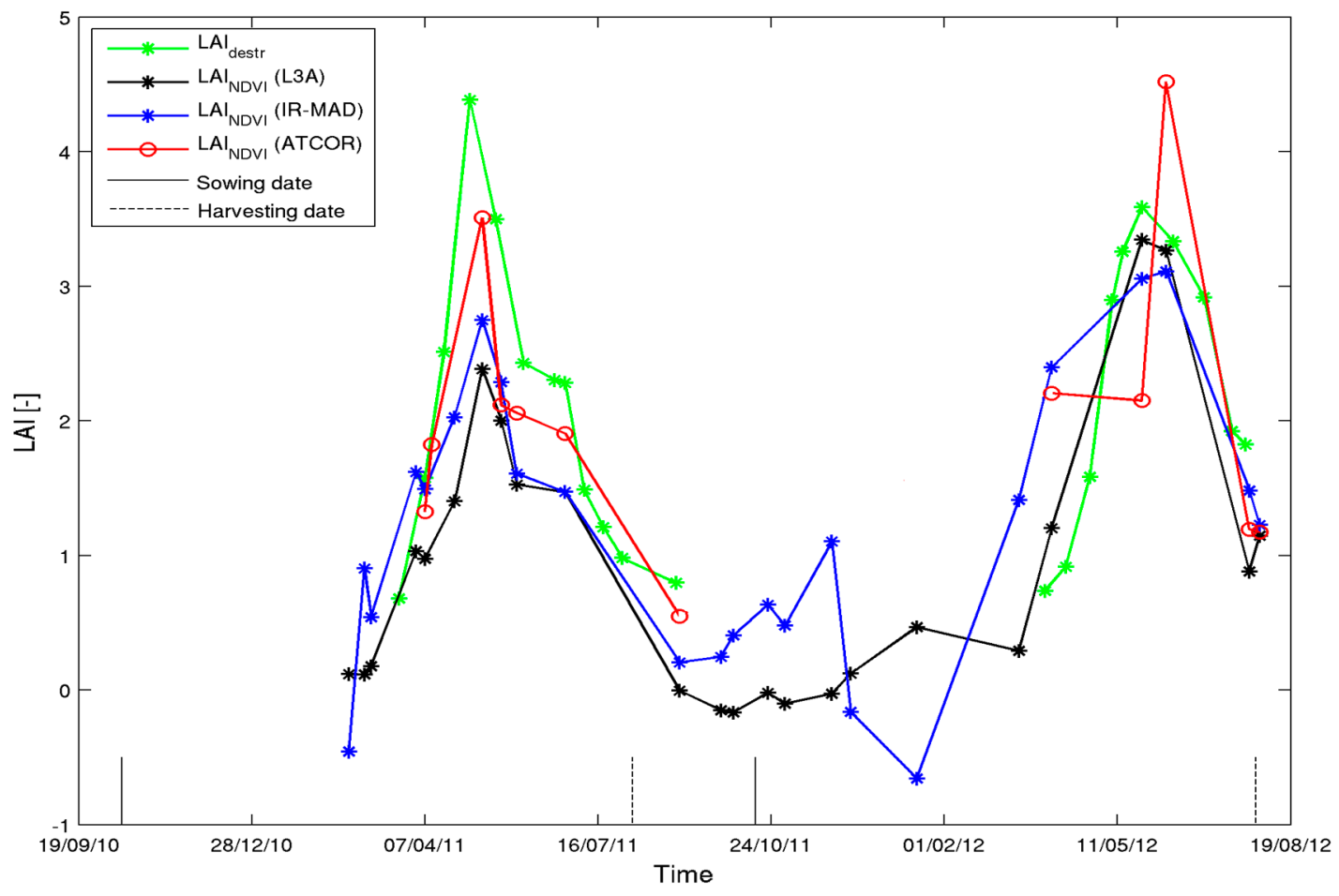

Figure 5. Temporal sequence of field-average destructive $\mathrm{LAI}_{\text {destr }}$ with remote sensing based

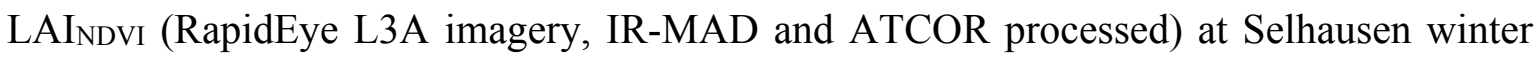
wheat field for 2011-2012.

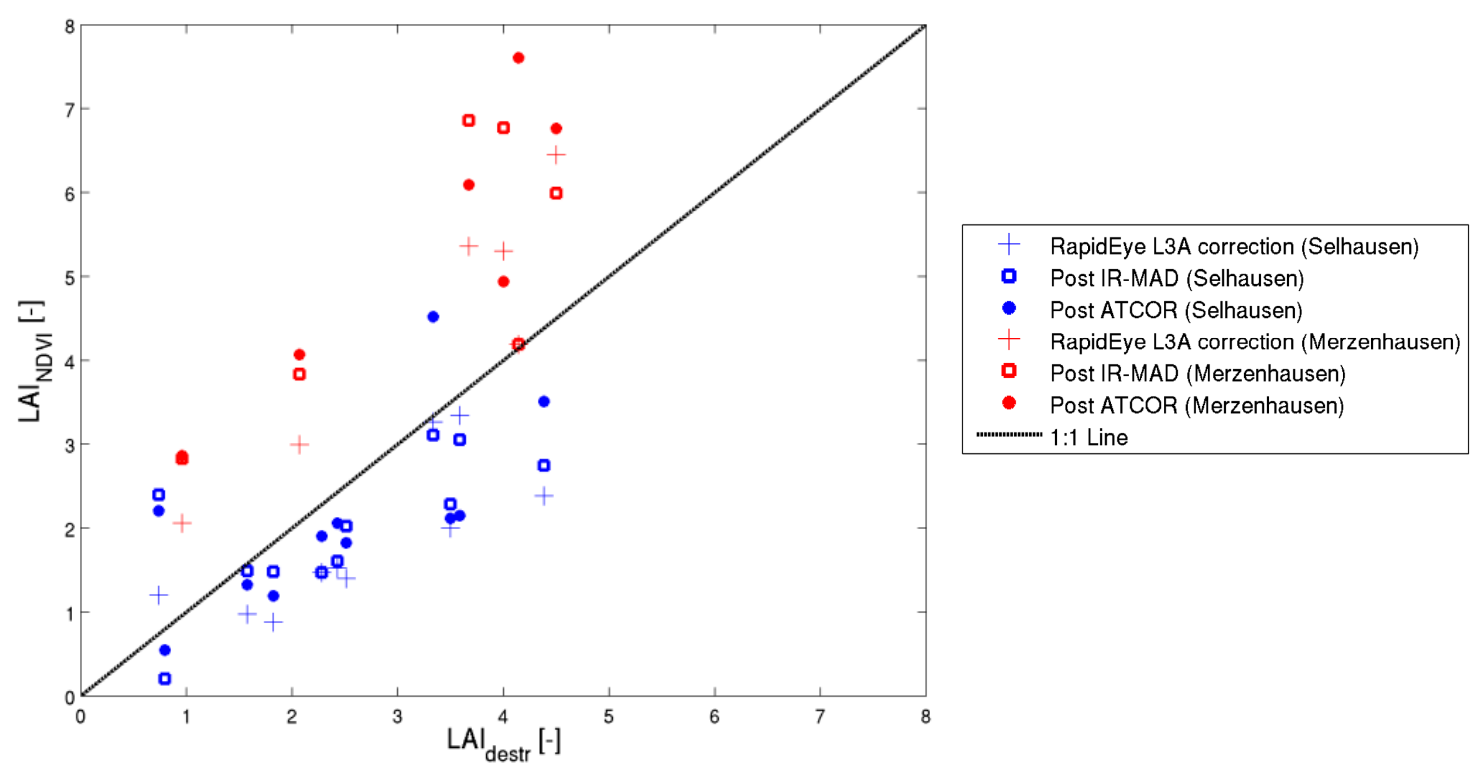

Figure 6. Scatter Plot of the LAINDVI (RapidEye standard L3A, IR-MAD and ATCOR processed) with LAIdestr for winter wheat field at Selhausen for 2011 and 2012 (blue) and at Merzenhausen for 2011 (red).

\subsection{Estimation of LAI Time-Series from RapidEye}

The ability of RapidEye data to adequately map in situ LAI is based on the adequate selection of the light extinction coefficient, $\mathrm{k}(\theta)$, in Equation (3). We evaluated a range of $\mathrm{k}(\theta)$ from 0 to 1 in 
Equation (3) for several vegetation indices of winter wheat (Figure 7). It was found that the value of $k(\theta)$ has no effect on the correlation coefficient, it only affects the RMSD. Figure 7 shows that selecting an appropriate empirical $\mathrm{k}(\theta)$ will reduce RMSD, but to minimize the RMSD for various vegetation indices different $\mathrm{k}(\theta)$ have to be selected. The present analysis showed that the use of a single $\mathrm{k}(\theta)$ is challenging for heterogeneous surfaces due to varying patterns of light transmission [81] and leaf morphology [82]. Aubin et al. [81], White et al. [82] and Propastin and Erasmi [40] calculated $\mathrm{k}$ values for different vegetation types. Aubin et al. [81] reported a mean k value of 0.54 with lowest (0.40) in a mixed forest whereas highest (0.98) in open coniferous forest. Propastin and Erasmi [40] calculated the extinction coefficient for an agro-forestry area using $30 \mathrm{~m}$ Landsat TM with a mean value of 0.45 (lowest 0.32 and highest 0.68 ). Values of $\mathrm{k}$ calculated by Propastin and Erasmi [40] were compatible with the kalues for the same biome by White et al. [82]. Generally, $\mathrm{k}(\theta)$ is set at 0.50 for all types of canopies (random distribution of leaf angles [83]). However, most suitable $\mathrm{k}(\theta)$ selection needs more experiments for different vegetation types and indices in different geographical regions for different spatial resolutions.

The light extinction coefficient " $k(\theta)$ " in Equation (3) has no effect on the correlation coefficient, but it was sensitive towards the RMSD. Therefore, a more appropriate $\mathrm{k}(\theta)$ was selected for different indices and test fields in order to get a minimum possible RMSD. To evaluate the applicability of the optimized $\mathrm{k}(\theta)$ for producing robust results, sample points from each test site were split into calibration and validation sets. The $\mathrm{k}(\theta)$ was optimized using the calibration set on the basis of lowest RMSD (Table 4). The cross validation was performed based on the validation set using the relevant optimized $\mathrm{k}(\theta)$ from Table 4. This validation produced consistent results as in Table 3. The model used here will generate reliable estimates of LAI if applied beyond the under observation test fields on the satellite data used in this study. The $\mathrm{k}(\theta)$ varies with spectral indices used, vegetation type and surface heterogeneity.

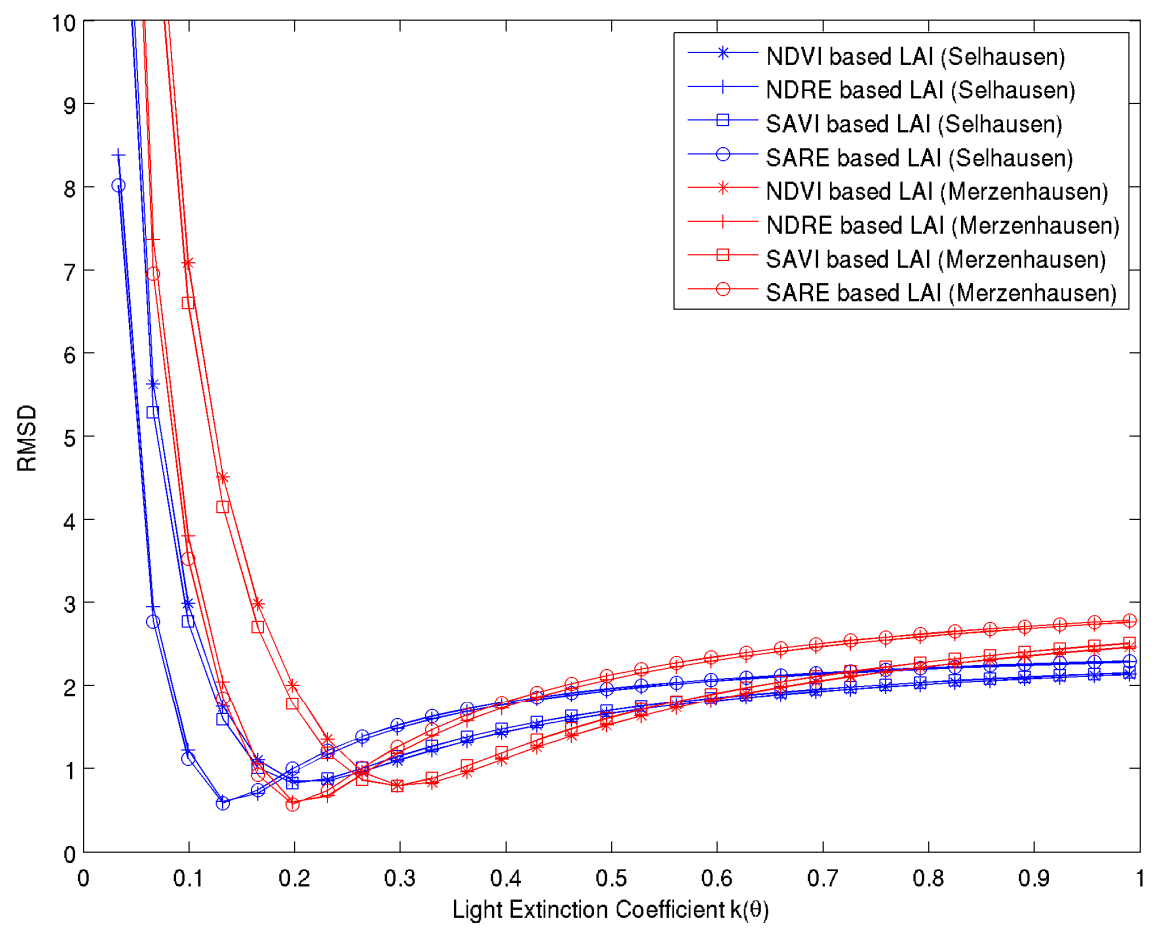

Figure 7. Comparison of the light extinction coefficient and RMSD for NDVI, NDRE, SAVI and SARE based LAI for the Selhausen and the Merzenhausen winter wheat fields. 
Table 4. Validation result through splitting the sample set into calibration and validation sets for LAI estimates from RapidEye.

\begin{tabular}{|c|c|c|c|c|c|c|}
\hline \multirow{2}{*}{$\begin{array}{l}\text { LAIrapideye vs. LAI } I_{\text {destr }} \\
\text { for Winter Wheat }\end{array}$} & \multicolumn{3}{|c|}{ Selhausen (2011-2012) } & \multicolumn{3}{|c|}{ Merzenhausen (2011) } \\
\hline & $\mathbf{k}(\theta)$ & $\mathbf{r}$ & RMSD & $\mathbf{k}(\boldsymbol{\theta})$ & $\mathbf{r}$ & RMSD \\
\hline $\mathrm{LAI}_{\mathrm{NDVI}}$ & 0.19 & 0.81 & 1.05 & 0.36 & 0.84 & 0.91 \\
\hline $\mathrm{LAI}_{\mathrm{NDRE}}$ & 0.12 & 0.88 & 1.01 & 0.22 & 0.84 & 0.86 \\
\hline LAI $_{\mathrm{SAVI}}$ & 0.19 & 0.81 & 0.96 & 0.34 & 0.84 & 0.89 \\
\hline $\mathrm{LAI}_{\text {SARE }}$ & 0.12 & 0.88 & 0.92 & 0.21 & 0.85 & 0.84 \\
\hline
\end{tabular}

The LAINDVI and LAIsAvi produced identical correlation results (Table 4) for both test sites. The $\mathrm{k}(\theta)$ is also similar for both the LAINDVI and LAISAVI for Selhausen $(\mathrm{k}(\theta)=0.19)$; however, the Merzenhausen site has higher $\mathrm{k}(\theta)$ and is slightly different for LAINDVI and LAISAVI $(\mathrm{k}(\theta)=0.36$ and 0.34 , respectively). Difference in $\mathrm{k}(\theta)$ is apparently due to the surface heterogeneity (in LAI) at both test sites. The Selhausen test field is more heterogeneous [59] as compared to the Merzenhausen site. Vegetation at the Merzenhausen test site is more homogeneous, healthier and dense, hence more light is trapped by the canopy causing higher $\mathrm{k}(\theta)$ (Table 4). Table 4 shows that using red-edge band instead of red band, reduces the light extinction coefficient, $\mathrm{k}(\theta)$. For using NDVI, the effect of mixed signals (including soil reflection) is minimized by calculating FVC (Equation (2)). In SAVI, the effect of soil reflection is reduced by incorporating soil brightness correction factor, L (Equation (5)). However, identical results for NDVI and SAVI exhibit the accuracy of the FVC calculation for NDVI and incorporating the soil brightness correction factor (L) in SAVI, in order to minimize the effect of bare soil reflections. Figure 8 (upper) shows identical temporal sequence for LAIsAVI and LAINDVI. Apparently, there was no advantage of replacing the NDVI by SAVI in this study. There is no improvement in the correlation statistics by correlating remotely sensed LAISAVI with LAIdestr as compared to the LAINDVI with LAIdestr. For smaller LAI, soil reflection (in red spectral band) affect LAI, however, for higher LAI, near infra-red reflectance from vegetation is dominant [24]. The in situ LAI data were taken from dates when there were enough plants in the test fields, i.e., when the need for soil adjustment in a spectral vegetation index is already reduced.

A time-series of the newly available red-edge (RE) spectral band in NDRE, SARE (Section 4.4) was analyzed and used for LAINDRE and LAISARE estimation. Correlation results of the LAINDRE and LAISARE with LAIdestr are shown in Table 4, and plotted together with LAI $_{\text {destr }}$ (Figure 8 (lower)). Ehammer et al. [43] analyzed the effect of incorporating RE in vegetation indices, but in all cases no improvement was reported. Our analysis (Tables 2 and 4) showed two different results in correlation statistics by using RE for better estimates of vegetation indices. It is evident from Table 2 that NDRE and SARE (based on red-edge band) gave better correlation coefficients ( $r=0.90$ and $r=0.92$ for Selhausen and Merzenhausen respectively) and higher correlation significance $(p<0.05)$. Second, LAI $\mathrm{IDRE}_{\mathrm{NDE}}$ and LAISARE exhibit better correlation coefficients for Selhausen $(r=0.88)$, whereas Merzenhausen presents identical correlation coefficient $(r)$ for all indices except LAISARE which presents $r=0.85$. It was already mentioned that for utilizing LAINDRE and LAISARE, a reduced light extinction coefficient, $\mathrm{k}(\theta)$, is optimal. Besides surface heterogeneity, spectral band selection in vegetation indices also affects the $\mathrm{k}(\theta)$ in Equation (3). The LAINDRE and LAISARE is preferable here due to better and more consistent correlation results. 

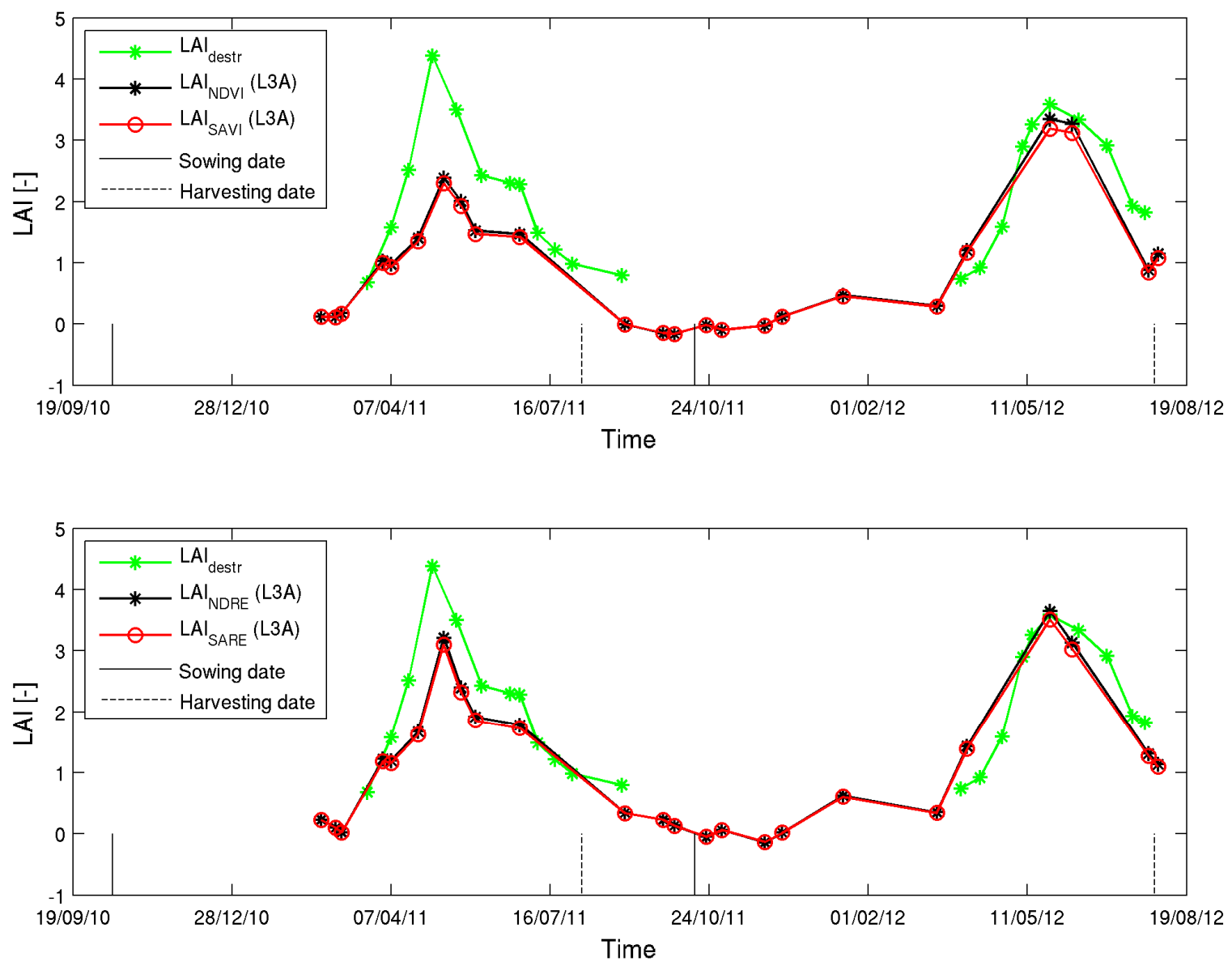

Figure 8. Temporal sequence of field-average destructive $\mathrm{LAI}_{\text {destr }}$ with remote sensing based

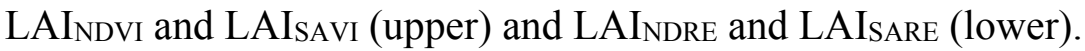

Additionally, the model (with a single $\mathrm{k}(\theta)=0.25$ ) was applied to the northern part of the Rur catchment (on L3A data) to develop a winter wheat LAI map (Figure 9) for 2 April 2011, using Rur catchment landuse map for 2011 [84]. The LAINDVI map has a mean LAI of 2.44 with a standard deviation of \pm 1.55 , whereas the LAINDRE has a mean LAI of 2.27 with standard deviation of \pm 1.25 . The mean LAI (in both cases) for winter wheat seems very reasonable on this date in the growing season.

Previous studies [44,45,48] reported improvement by using RE in vegetation based studies.

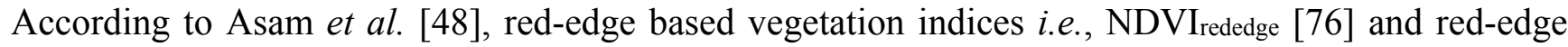
ration index 1 [43] improve regression modelling. They declare red-edge band suitable for LAI mapping in grassland. Eitel et al. [44] reported improvement in conifer woodland stress detection from satellite based red-edge monitoring. According to Eitel et al. [44], NDRE improves the stress detection in conifer woodland as compared to the traditionally used NDVI and green NDVI. Schuster et al. [45] reported improvement in classification accuracy of the vegetation classes (land use) using RE. Spectral reflectance in RE is comparatively higher than in RED, and it represents gradual increase in reflectance towards NIR (as shown in Figure 2). Figure 2 shows that the RE band is more sensitive towards vegetation (highly sensitive to the chlorophyll content [46]) than the red band. This study has shown that incorporating reflectance values captured in $\mathrm{RE}$ into various vegetation indices improve the validation results (Tables 2 and 4) as compared to the red-based vegetation indices (NDVI and SAVI). 


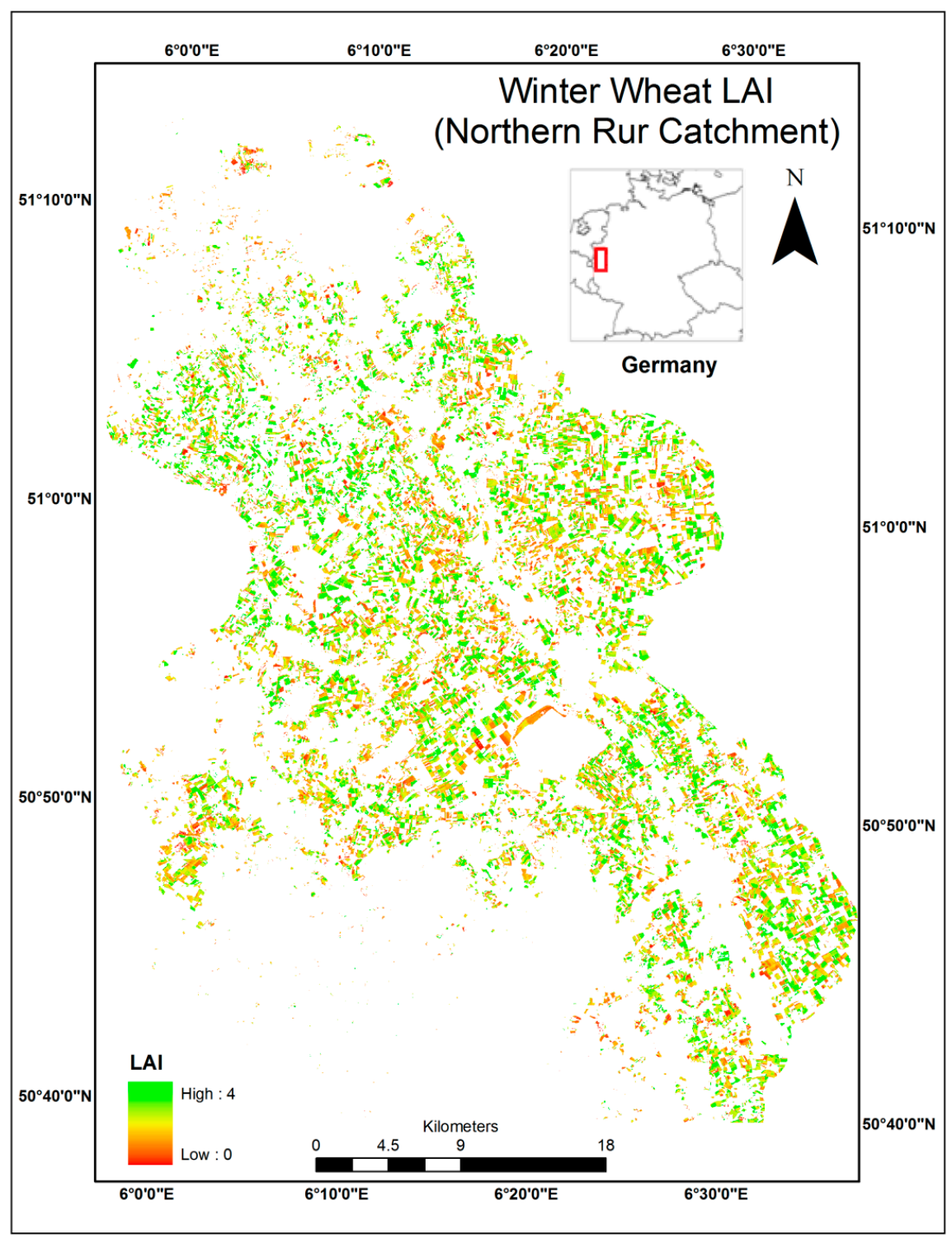

Figure 9. Winter wheat LAINDRE map of the northern Rur Catchment for 2 April 2011.

\section{Conclusions and Outlook}

The ability of RapidEye to provide time-series of leaf area index (LAI) for winter wheat was evaluated in the Rur catchment, Germany, focusing on two fields where destructive in situ LAI measurements (LAI $\left.\mathrm{Lestr}_{\text {r }}\right)$ were available.

It was found that time-series of various spectral vegetation indices (NDVI, NDRE, SAVI, and SARE) were highly correlated to the time-series of $\mathrm{LAI}_{\text {destr, }}$ where the red-edge-based indices NDRE and SARE provided the best correlations. Three atmospheric correction methods-namely the Standard RapidEyeLevel 3A delivery, the additional relative narmalization method IR-MAD as well as the additional absolute ATCOR correction - were evaluated according to their correlation to in situ LAI. IR-MAD processed imagery shows generally lower correlation than that on L3A images. For ATCOR, the direct correlation of the spectral index to $L A I_{\text {destr }}$ is very high for a relatively homogeneous field (Merzenhausen), but very low for a relatively heterogeneous field (Selhausen). Further analysis based on NDVI-related calculation of LAI found for ATCOR relatively large RMSE, whereas for the standard 
RapidEye L3A product a moderate RMSE was observed. With these results, we came to the conclusion that additional atmospheric correction is not necessary for generating time-series of LAI from RapidEye. Therefore, the following analysis was performed on the standard L3A product only.

In general, the estimation of LAI time-series for the two fields in focus was possible with adequate accuracy. The absolute prediction accuracy in terms of RMSD to predict LAIdestr time-series by RapidEye was found to be sensitive to the selection of the light extinction coefficient $k(\theta)$. In this study, the entire valid range $(0-1)$ of $\mathrm{k}(\theta)$ was optimized for minimizing the RMSD between LAI estimations

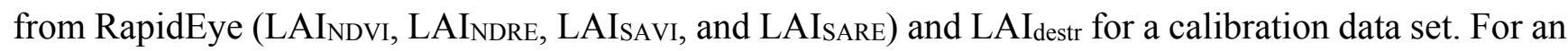
independent validation data set, the optimized $\mathrm{k}(\theta)$ was used to predict LAI.

Owing to the surface heterogeneity of the two fields in focus, varying patterns of radiation transmission [81] and selection of spectral bands, it was not possible to identify a single $\mathrm{k}(\theta)$ valid for large area LAI mapping. Optimum $\mathrm{k}(\theta)$ varied between 0.12 and 0.36 , where in general it was lower for the Selhausen field than for the Merzenhausen field. Incorporating the soil contribution into the LAI estimation by the Soil Adjusted Vegetation Index (SAVI) resulted in the same optimum $\mathrm{k}(\theta)$ and correlation coefficient, but it did not significantly improve RMSD. However, the implementation of the red-edge spectral band in the LAI estimation by the Normalized Difference Red-edge Index (NDRE) and the newly introduced Soil Adjusted Red-edge Index (SARE) reduced the optimum $\mathrm{k}(\theta)$, slightly increased the correlation coefficient and slightly reduced RMSD. Results from the present study suggest the use of the red-edge spectral band in NDRE and SARE for better estimates of LAI on RapidEye satellite imagery.

This validation study at hand was exclusively carried out for winter wheat, and further studies are needed for other crops and vegetation types (grasslands and forests). The high spatial resolution of RapidEye could be used for large scale SVAT (Soil Vegetation Atmosphere Transfer) models by providing generalized Plant Functional Type (PFT) parameters for different land cover types. Using more precise and high resolution estimates of remotely sensed LAI in hydrological and radiative transfer models may improve soil moisture [85] and evapotranspiration retrieval [86]. Remotely sensed fine resolution LAI maps identify the field scale variability of vegetation and it could be used to identify the subsoil heterogeneity in addition to geophysical methods [59]. Moreover, the analysis of the red-edge spectral band impact to LAI estimation provides basic information also for the upcoming Sentinel-2 mission [87].

\section{Acknowledgments}

This study is supported by the Higher Education Commission (HEC) of Pakistan through the German Academic Exchange Service (DAAD). It is incorporated in the Transregional Collaborative Research Centre 32 (TR32): "Patterns in Soil-Vegetation-Atmosphere Systems: Monitoring, modeling and data assimilation" from the German Research Foundation (DFG). RapidEye data have been provided by the RapidEye/Blackbridge Science Archive (RESA) under the collaboration with Terrestrial Environmental Observatories (TERENO). We are thankful to our colleagues from TR32 project C3 (Karl Schneider, Institute of Geography, University of Cologne, Germany), for providing additional destructive LAI data for the Merzenhausen test field. 


\section{Author Contributions}

Carsten Montzka and Harry Vereecken contributed to the concept design and improvement of the manuscript. Anja Stadler measured the destructive LAIdestr. Gunter Menz provided valuable suggestions to improve the manuscript. Frank Thonfeld applied the ATCOR processing on the data and contributed to the design of validation test. Muhammad Ali performed the research (image processing) and prepared the manuscript.

\section{Conflicts of Interest}

The authors declare no conflict of interest.

\section{References}

1. Mu, Q.Z.; Zhao, M.S.; Running, S.W. Evolution of hydrological and carbon cycles under a changing climate. Part iii: Global change impacts on landscape scale evapotranspiration. Hydrol. Process. 2011, 25, 4093-4102.

2. Weiss, J.L.; Gutzler, D.S.; Coonrod, J.E.A.; Dahm, C.N. Seasonal and inter-annual relationships between vegetation and climate in central new Mexico, USA. J. Arid. Environ. 2004, 57, 507-534.

3. Arora, V. Modeling vegetation as a dynamic component in soil-vegetation-atmosphere transfer schemes and hydrological models. Rev. Geophys. 2002, 40, doi:10.1029/2001RG000103.

4. Sellers, P.J.; Dickinson, R.E.; Randall, D.A.; Betts, A.K.; Hall, F.G.; Berry, J.A.; Collatz, G.J.; Denning, A.S.; Mooney, H.A.; Nobre, C.A.; et al. Modeling the exchanges of energy, water, and carbon between continents and the atmosphere. Science 1997, 275, 502-509.

5. Ge, J.J. On the proper use of satellite-derived leaf area index in climate modeling. J. Clim. 2009, $22,4427-4433$.

6. Atzberger, C. Advances in remote sensing of agriculture: Context description, existing operational monitoring systems and major information needs. Remote Sens. 2013, 5, 949-981.

7. Rembold, F.; Atzberger, C.; Savin, I.; Rojas, O. Using low resolution satellite imagery for yield prediction and yield anomaly detection. Remote Sens. 2013, 5, 1704-1733.

8. Jonckheere, I.; Fleck, S.; Nackaerts, K.; Muys, B.; Coppin, P.; Weiss, M.; Baret, F. Review of methods for in situ leaf area index determination-Part i. Theories, sensors and hemispherical photography. Agric. For. Meteorol. 2004, 121, 19-35.

9. Curran, P.J. Multispectral remote-sensing for the estimation of green leaf-area index. Philos. Trans. R. Soc. A Math. Phys. Eng. Sci. 1983, 309, 257-270.

10. Verhoef, W. Light-scattering by leaf layers with application to canopy reflectance modeling-The sail model. Remote Sens. Environ. 1984, 16, 125-141.

11. Jacquemoud, S.; Verhoef, W.; Baret, F.; Bacour, C.; Zarco-Tejada, P.J.; Asner, G.P.; Francois, C.; Ustin, S.L. Prospect plus sail models: A review of use for vegetation characterization. Remote Sens. Environ. 2009, 113, S56-S66.

12. Haboudane, D.; Miller, J.R.; Pattey, E.; Zarco-Tejada, P.J.; Strachan, I.B. Hyperspectral vegetation indices and novel algorithms for predicting green lai of crop canopies: Modeling and validation in the context of precision agriculture. Remote Sens. Environ. 2004, 90, 337-352. 
13. Clevers, J.G.P.W. Application of remote sensing to agricultural field trials. Wagening. Agric. Univ. Pap. 1986, 86, 1-227.

14. Clevers, J. The derivation of a simplified reflectance model for the estimation of leaf-area index. Remote Sens. Environ. 1988, 25, 53-69.

15. Clevers, J. The application of a weighted infrared-red vegetation index for estimating leaf-area index by correcting for soil-moisture. Remote Sens. Environ. 1989, 29, 25-37.

16. Colombo, R.; Bellingeri, D.; Fasolini, D.; Marino, C.M. Retrieval of leaf area index in different vegetation types using high resolution satellite data. Remote Sens. Environ. 2003, 86, 120-131.

17. Walthall, C.; Dulaney, W.; Anderson, M.; Norman, J.; Fang, H.L.; Liang, S.L. A comparison of empirical and neural network approaches for estimating corn and soybean leaf area index from Landsat ETM+ imagery. Remote Sens. Environ. 2004, 92, 465-474.

18. Cohen, W.B.; Maiersperger, T.K.; Gower, S.T.; Turner, D.P. An improved strategy for regression of biophysical variables and Landsat ETM+ data. Remote Sens. Environ. 2003, 84, 561-571.

19. Atzberger, C.; Guerif, M.; Baret, F.; Werner, W. Comparative analysis of three chemometric techniques for the spectroradiometric assessment of canopy chlorophyll content in winter wheat. Comput. Electron. Agric. 2010, 73, 165-173.

20. Mirzaie, M.; Darvishzadeh, R.; Shakiba, A.; Matkan, A.A.; Atzberger, C.; Skidmore, A. Comparative analysis of different uni- and multi-variate methods for estimation of vegetation water content using hyper-spectral measurements. Int. J. Appl. Earth Obs. Geoinf. 2014, 26, 1-11.

21. Thorp, K.R.; Batchelor, W.D.; Paz, J.O.; Kaleita, A.L.; DeJonge, K.C. Using cross-validation to evaluate ceres-maize yield simulations within a decision support system for precision agriculture. Trans. ASABE 2007, 50, 1467-1479.

22. Deng, F.; Chen, J.M.; Plummer, S.; Chen, M.Z.; Pisek, J. Algorithm for global leaf area index retrieval using satellite imagery. IEEE Trans. Geosci. Remote Sens. 2006, 44, 2219-2229.

23. Vuolo, F.; Atzberger, C.; Richter, K.; D’Urso, G.; Dash, J. Retrieval of biophysical vegetation products from rapideye imagery. 100 Years ISPRS Adv. Remote Sens. Sci. Part 1 2010, 38, 281-286.

24. Asrar, G.; Fuchs, M.; Kanemasu, E.T.; Hatfield, J.L. Estimating absorbed photosynthetic radiation and leaf-area index from spectral reflectance in wheat. Agron. J. 1984, 76, 300-306.

25. Baret, F.; Guyot, G. Potentials and limits of vegetation indexes for LAI and APAR assessment. Remote Sens. Environ. 1991, 35, 161-173.

26. Rouse, J.W.; Haas, R.H.; Schell, J.A.; Deering, D.W. Monitoring vegetation systems in the great plains with ERTS. In Proceedings of the Third Earth Resources Technology Satellite-1 Symposium, NASA SP-351, Washington, DC, USA, 10-14 December 1973, pp. 309-317.

27. Huete, A.R. A soil-adjusted vegetation index (SAVI). Remote Sens. Environ. 1988, 25, 295-309.

28. Xie, Y.C.; Sha, Z.Y.; Yu, M. Remote sensing imagery in vegetation mapping: A review. J. Plant Ecol. 2008, 1, 9-23.

29. Vereecken, H.; Weihermuller, L.; Jonard, F.; Montzka, C. Characterization of crop canopies and water stress related phenomena using microwave remote sensing methods: A review. Vadose Zone J. 2012, 11, doi:10.2136/vzj2011.0138ra.

30. Duggin, M.J.; Piwinski, D. Recorded radiance indexes for vegetation monitoring using noaa AVHRR data-Atmospheric and other effects in multitemporal data sets. Appl. Opt. 1984, 23, $2620-2623$. 
31. Gao, F.; Anderson, M.C.; Kustas, W.P.; Wang, Y.J. Simple method for retrieving leaf area index from landsat using MODIS leaf area index products as reference. J. Appl. Remote Sens. 2012, 6, doi:10.1117/1.JRS.6.063554.

32. Propastin, P.; Panferov, O. Retrieval of remotely sensed LAI using Landsat ETM plus data and ground measurements of solar radiation and vegetation structure: Implication of leaf inclination angle. Int. J. Appl. Earth Obs. Geoinf. 2013, 25, 38-46.

33. Barnett, T.L.; Thompson, D.R. Large-area relation of landsat mss and NOAA-6 AVHRR spectral data to wheat yields. Remote Sens. Environ. 1983, 13, 277-290.

34. Chen, J.M.; Cihlar, J. Retrieving leaf area index of boreal conifer forests using Landsat TM images. Remote Sens. Environ. 1996, 55, 153-162.

35. Turner, D.P.; Cohen, W.B.; Kennedy, R.E.; Fassnacht, K.S.; Briggs, J.M. Relationships between leaf area index and Landsat TM spectral vegetation indices across three temperate zone sites. Remote Sens. Environ. 1999, 70, 52-68.

36. Pu, R.L.; Gong, P. Wavelet transform applied to EO-1 hyperspectral data for forest LAI and crown closure mapping. Remote Sens. Environ. 2004, 91, 212-224.

37. Schlerf, M.; Atzberger, C. Inversion of a forest reflectance model to estimate structural canopy variables from hyperspectral remote sensing data. Remote Sens. Environ. 2006, 100, 281-294.

38. Norman, J.M.; Kustas, W.P.; Humes, K.S. Source approach for estimating soil and vegetation energy fluxes in observations of directional radiometric surface-temperature. Agric. For. Meteorol. 1995, 77, 263-293.

39. Sprintsin, M.; Karnieli, A.; Berliner, P.; Rotenberg, E.; Yakir, D.; Cohen, S. The effect of spatial resolution on the accuracy of leaf area index estimation for a forest planted in the desert transition zone. Remote Sens. Environ. 2007, 109, 416-428.

40. Propastin, P.; Erasmi, S. A physically based approach to model LAI from MODIS $250 \mathrm{~m}$ data in a tropical region. Int. J. Appl. Earth Obs. Geoinf. 2010, 12, 47-59.

41. Ullah, S.; Si, Y.; Schlerf, M.; Skidmore, A.K.; Shafique, M.; Iqbal, I.A. Estimation of grassland biomass and nitrogen using MERIS data. Int. J. Appl. Earth Obs. Geoinf. 2012, 19, 196-204.

42. Darvishzadeh, R.; Atzberger, C.; Skidmore, A.K.; Abkar, A.A. Leaf area index derivation from hyperspectral vegetation indices and the red edge position. Int. J. Remote Sens. 2009, 30, 6199-6218.

43. Ehammer, A.; Fritsch, S.; Conrad, C.; Lamers, J.; Dech, S. Statistical derivation of FPAR and LAI for irrigated cotton and rice in arid uzbekistan by combining multi-temporal Rapideye data and ground measurements. Proc. SPIE 2010, 7824, doi:10.1117/12.864796.

44. Eitel, J.U.H.; Vierling, L.A.; Litvak, M.E.; Long, D.S.; Schulthess, U.; Ager, A.A.; Krofcheck, D.J.; Stoscheck, L. Broadband, red-edge information from satellites improves early stress detection in a new mexico conifer woodland. Remote Sens. Environ. 2011, 115, 3640-3646.

45. Schuster, C.; Forster, M.; Kleinschmit, B. Testing the red edge channel for improving land-use classifications based on high-resolution multi-spectral satellite data. Int. J. Remote Sens. 2012, 33, 5583-5599.

46. Filella, I.; Penuelas, J. The red edge position and shape as indicators of plant chloro phyll content, biomass and hydric status. Int. J. Remote Sens. 1994, 15, 1459-1470. 
47. Eitel, J.U.H.; Long, D.S.; Gessler, P.E.; Smith, A.M.S. Using in-situ measurements to evaluate the new Rapideye (TM) satellite series for prediction of wheat nitrogen status. Int. J. Remote Sens. 2007, 28, 4183-4190.

48. Asam, S.; Fabritius, H.; Klein, D.; Conrad, C.; Dech, S. Derivation of leaf area index for grassland within alpine upland using multi-temporal Rapideye data. Int. J. Remote Sens. 2013, 34, 8628-8652.

49. Hadjimitsis, D.G.; Papadavid, G.; Agapiou, A.; Themistocleous, K.; Hadjimitsis, M.G.; Retalis, A.; Michaelides, S.; Chrysoulakis, N.; Toulios, L.; Clayton, C.R.I. Atmospheric correction for satellite remotely sensed data intended for agricultural applications: Impact on vegetation indices. Nat. Hazards Earth Syst. Sci. 2010, 10, 89-95.

50. Yang, X.J.; Lo, C.P. Relative radiometric normalization performance for change detection from multi-date satellite images. Photogramm. Eng. Remote Sens. 2000, 66, 967-980.

51. Hall, F.G. Radiometric rectification: Toward a common radiometric response among multidate, multisensor imageses. Remote Sens. Environ. 1991, 35, 11-27.

52. Montzka, C.; Canty, M.; Kunkel, R.; Menz, G.; Vereecken, H.; Wendland, F. Modelling the water balance of a mesoscale catchment basin using remotely sensed land cover data. J. Hydrol. 2008, 353, 322-334.

53. Montzka, C.; Canty, M.; Kreins, P.; Kunkel, R.; Menz, G.; Vereecken, H.; Wendland, F. Multispectral remotely sensed data in modelling the annual variability of nitrate concentrations in the leachate. Environ. Modell. Softw. 2008, 23, 1070-1081.

54. TERRESTRIAL ENVIRONMENTAL OBSERVATORIES (TERENO). Available online: http://teodoor.icg.kfa-juelich.de/overview-en (accessed on 5 March 2015).

55. Zacharias, S.; Bogena, H.; Samaniego, L.; Mauder, M.; Fuss, R.; Putz, T.; Frenzel, M.; Schwank, M.; Baessler, C.; Butterbach-Bahl, K.; et al. A network of terrestrial environmental observatories in germany. Vadose Zone J. 2011, 10, 955-973.

56. Montzka, C.; Bogena, H.R.; Weihermuller, L.; Jonard, F.; Bouzinac, C.; Kainulainen, J.; Balling, J.E.; Loew, A.; Dall'Amico, J.T.; Rouhe, E.; et al. Brightness temperature and soil moisture validation at different scales during the SMOS validation campaign in the RUR and ERFT catchments, Germany. IEEE Trans. Geosci. Remote Sens. 2013, 51, 1728-1743.

57. Bogena, H.; Kunkel, R.; Schobel, T.; Schrey, H.P.; Wendland, E. Distributed modeling of groundwater recharge at the macroscale. Ecol. Model. 2005, 187, 15-26.

58. Rötzer, K.; Montzka, C.; Bogena, H.; Wegner, W.; Kerr, Y.H.; Kidd, R.; Vereecken, H. Catchment scale validation of SMOS and ASCAT soil moisture products using hydrological modeling and temporal stability analysis. J. Hydrol. 2014, 519, 934-946.

59. Rudolph, S.; van der Kruk, J.; von Hebel, C.; Ali, M.; Herbst, M.; Montzka, C.; Pätzold, S.; Robinson, D.A.; Vereecken, H.; Weihermüller, L. Linking satellite derived lai patterns with subsoil heterogeneity using large-scale ground-based electromagnetic induction measurements. Geoderma 2015, 241-242, 262-271.

60. Weihermuller, L.; Huisman, J.A.; Lambot, S.; Herbst, M.; Vereecken, H. Mapping the spatial variation of soil water content at the field scale with different ground penetrating radar techniques. J. Hydrol. 2007, 340, 205-216. 
61. Weihermueller, L. Comparison of Different Soil Water Extraction Systems for the Prognoses of Solute Transport at the Field Scale Using Numerical Simulations, Field and Lysimeter Experiments. Available online: http://hss.ulb.uni-bonn.de/2005/0573/0573-engl.htm (accessed on 9 March 2015).

62. BlackBridge-RapidEye. Satellite Imagery Product Specifications. 2013. Available online: http://www.blackbridge.com/rapideye/upload/RE_Product_Specifications_ENG.pdf (accessed on 5 March 2015).

63. Breda, N.J.J. Ground-based measurements of leaf area index: A review of methods, instruments and current controversies. J. Exp. Bot. 2003, 54, 2403-2417.

64. Stadler, A.; Rudolph, S.; Kupisch, M.; Langensiepen, M.; van der Kruk, J.; Ewert, F. Quantifying the effects of soil variability on crop growth using apparent soil electrical conductivity measurements. Europ. J. Agron. 2015, 64, 8-20.

65. Canty, M.J.; Nielsen, A.A. Automatic radiometric normalization of multitemporal satellite imagery with the iteratively re-weighted mad transformation. Remote Sens. Environ. 2008, 112, 1025-1036.

66. Canty, M.J.; Nielsen, A.A.; Schmidt, M. Automatic radiometric normalization of multitemporal satellite imagery. Remote Sens. Environ. 2004, 91, 441-451.

67. Richter, R. Atmospheric correction of satellite data with haze removal including a haze/clear transition region. Comput. Geosci. 1996, 22, 675-681.

68. Richter, R. A spatially adaptive fast atmospheric correction algorithm. Int. J. Remote Sens. 1996, 17, 1201-1214.

69. Geerken, R.; Zaitchik, B.; Evans, J.P. Classifying rangeland vegetation type and coverage from ndvi time series using fourier filtered cycle similarity. Int. J. Remote Sens. 2005, 26, 5535-5554.

70. Beck, P.S.A.; Atzberger, C.; Hogda, K.A.; Johansen, B.; Skidmore, A.K. Improved monitoring of vegetation dynamics at very high latitudes: A new method using MODIS NDVI. Remote Sens. Environ. 2006, 100, 321-334.

71. Zeng, X.B.; Rao, P.; DeFries, R.S.; Hansen, M.C. Interannual variability and decadal trend of global fractional vegetation cover from 1982 to 2000. J. Appl. Meteorol. 2003, 42, 1525-1530.

72. Zeng, X.B.; Dickinson, R.E.; Walker, A.; Shaikh, M.; DeFries, R.S.; Qi, J.G. Derivation and evaluation of global 1-km fractional vegetation cover data for land modeling. J. Appl. Meteorol. 2000, 39, 826-839.

73. Xiao, J.F.; Moody, A. A comparison of methods for estimating fractional green vegetation cover within a desert-to-upland transition zone in central new mexico, USA. Remote Sens. Environ. 2005, 98, 237-250.

74. Norman, J.M.; Kustas, W.P.; Humes, K.S. Source approach for estimating soil and vegetation energy fluxes in observations of directional radiometric surface temperature (vol 77, pg 263, 1995). Agric. For. Meteorol. 1996, 80, 297-297.

75. Sims, D.A.; Gamon, J.A. Relationships between leaf pigment content and spectral reflectance across a wide range of species, leaf structures and developmental stages. Remote Sens. Environ. 2002, 81, $337-354$.

76. Gitelson, A.; Merzlyak, M.N. Spectral reflectance changes associated with autumn senescence of aesculus-hippocastanum 1 and acer-platanoides 1 leaves-Spectral features and relation to chlorophyll estimation. J. Plant Physiol. 1994, 143, 286-292. 
77. Gitelson, A.; Merzlyak, M.N. Quantitative estimation of chlorophyll-a using reflectance spectra-Experiments with autumn chestnut and maple leaves. J. Photochem. Photobiol. B Biol. 1994, 22, 247-252.

78. Gu, Z.J.; Shi, X.Z.; Li, L.; Yu, D.S.; Liu, L.S.; Zhang, W.T. Using multiple radiometric correction images to estimate leaf area index. Int. J. Remote Sens. 2011, 32, 9441-9454.

79. Abdou, W.A.; Pilorz, S.H.; Helmlinger, M.C.; Conel, J.E.; Diner, D.J.; Bruegge, C.J.; Martonchik, J.V.; Gatebe, C.K.; King, M.D.; Hobbs, P.V. Sua pan surface bidirectional reflectance: A case study to evaluate the effect of atmospheric correction on the surface products of the multi-angle imaging spectroradiometer (MISR) during safari 2000. IEEE Trans. Geosci. Remote Sens. 2006, 44, 1699-1706.

80. Qi, J.; Marsett, R.C.; Moran, M.S.; Goodrich, D.C.; Heilman, P.; Kerr, Y.H.; Dedieu, G.; Chehbouni, A.; Zhang, X.X. Spatial and temporal dynamics of vegetation in the san pedro river basin area. Agric. For. Meteorol. 2000, 105, 55-68.

81. Aubin, I.; Beaudet, M.; Messier, C. Light extinction coefficients specific to the understory vegetation of the southern boreal forest, Quebec. Can. J. For. Res. Rev. Can. Rech. For. 2000, 30, $168-177$.

82. White, M.A.; Thornton, P.E.; Running, S.W.; Nemani, R.R. Parametrization and sensitivity analysis of the biome-bgc terrestrial ecosystem model: Net primary production controls. Earth Interact. 2000, 4, 1-85.

83. Chen, J.M.; Blanken, P.D.; Blank, T.A.; Guilbeault, M.; Chen, S. Radiation regime and canopy architecture in a boreal aspen forest. Agric. For. Meteorol. 1997, 86, 107-125.

84. Lussem, U.; Waldhoff, G. Enhanced Land Use Classification of 2011 for the Rur Catchment. Available online: http://www.tr32db.uni-koeln.de/site/index.php (accessed on 9 March 2015).

85. Hasan, S.; Montzka, C.; Rudiger, C.; Ali, M.; Bogena, H.R.; Vereecken, H. Soil moisture retrieval from airborne l-band passive microwave using high resolution multispectral data. ISPRS J. Photogramm. Remote Sens. 2014, 91, 59-71.

86. Duchemin, B.; Hadria, R.; Erraki, S.; Boulet, G.; Maisongrande, P.; Chehbouni, A.; Escadafal, R.; Ezzahar, J.; Hoedjes, J.C.B.; Kharrou, M.H.; et al. Monitoring wheat phenology and irrigation in central morocco: On the use of relationships between evapotranspiration, crops coefficients, leaf area index and remotely-sensed vegetation indices. Agric. Water Manag. 2006, 79, 1-27.

87. Delegido, J.; Verrelst, J.; Alonso, L.; Moreno, J. Evaluation of sentinel-2 red-edge bands for empirical estimation of green LAI and chlorophyll content. Sensors 2011, 11, 7063-7081.

(C) 2015 by the authors; licensee MDPI, Basel, Switzerland. This article is an open access article distributed under the terms and conditions of the Creative Commons Attribution license (http://creativecommons.org/licenses/by/4.0/). 